УДК 634.8:579.2

DOI 10.30679/2219-5335-2021-4-70-240-253

\section{СРАВНИТЕЛЬНО-ЭКОЛОГИЧЕСКИЕ ИССЛЕДОВАНИЯ КОМПЛЕКСОВ МИКРОМИЦЕТОВ, АССОЦИИРОВАННЫХ С ЛОЗОЙ ДИКОРАСТУЩЕГО И КУЛЬТИВИРУЕМОГО ВИНОГРАДА В ЗАПАДНОМ ПРЕДКАВКАЗЬЕ (РОССИЯ)*}

Юрченко Евгения Георгиевна ${ }^{1}$ канд. с.-х. наук зав. научным центром защиты и биотехнологии растений

Лукьянова Анна Александровна ${ }^{2}$ канд. биол. наук научный сотрудник лаборатории виноградарства и виноделия

Горбунов Иван Викторович ${ }^{2}$ канд. биол. наук научный сотрудник лаборатории виноградарства и виноделия

${ }^{1}$ Федеральное государственное бюджетное научное учреждение «Северо-Кавказский федеральный научный иентр садоводства, виноградарства, виноделия», Краснодар, Россия

${ }^{2}$ Анапская зональная опытная станичия виноградарства и виноделия филиал Федерального государственного бюджетного научного учреждения «Северо-Кавказский федеральный научный иентр садоводства, виноградарства, виноделия», Aнапа, Россия

UDC 634.8:579.2

DOI 10.30679/2219-5335-2021-4-70-240-253

\title{
COMPARATIVE ECOLOGICAL STUDIES OF MICROMYCETE COMPLEXES ASSOCIATED WITH VARIOUS VINE OF WILD AND CULTIVATED GRAPES IN THE WESTERN CISCAUCASIA (RUSSIA)*
}

Yurchenko Eugeniya Georgievna ${ }^{1}$, Cand. Agr. Sci. Head of SC Protection and Biotechnology of Plants

Lukyanova Anna Alexsandrovna ${ }^{2}$ Cand. Biol. Sci.

Research Associate of Viticulture and Wine-making Laboratory

Gorbunov Ivan Viktorovich ${ }^{2}$ Cand. Biol. Sci.

Research Associate of Viticulture and Wine-making Laboratory

${ }^{1}$ Federal State Budget Scientific Institution "North Caucasian Federal Scientific Center of Horticulture, Viticulture, Wine-making», Krasnodar, Russia

${ }^{2}$ Anapa Zonal Experimental Station
of Viticulture and Wine-making-
Branch of Federal State
Budgetary Scientific Institution
"North-Caucasus Federal
Scientific Center of Horticulture,
Viticulture, Wine-making»,
Anapa, Russia

\footnotetext{
* Исследование выполнено при финансовой поддержке Кубанского научного фонда в рамках научного проекта № МФИ-20.1/25».

* The research was carried out with the financial support of the Kuban science Foundation in the framework of the scientific project № MFI-20.1/25».
} 
Оценка разнообразия грибных сообществ и изучение биоиндикационной значимости микологических показателей актуальна для биомониторинга ампелоценозов. В данной статье показаны результаты изучения количественного и качественного состава сообществ сапротрофных микромицетов, ассоциированных с однолетними побегами дикорастущих и культурных растений винограда. Изучение проводилось в 2020 году в различных районах Краснодарского края (Западное Предкавказье). Объектами исследования были дикорастущие виноградные растения из естественных условий лесных экотопов государственного заповедника «Утриш» (Анапский район) и Крымского района, а также культурные виноградные растения 4-х сортов различных по генотипу, возделывающиеся в насаждениях АО агрофирмы «Южная» (Темрюкский район). Исследования показали, что численность сапротрофных микромицетов, ассоциированных с однолетней лозой различна в зависимости от места отбора образца и колеблется в пределах 232,9...3203,2 тыс. КОЕ/Г сухого вещества на дикорастущем винограде и в пределах $118,9 \ldots 344,1$ тыс. КОЕ/г сухого вещества на культурном винограде. Самые высокие показатели плотности грибных популяций 1119,7 и 3203,2 КОЕ/г сухого вещества были зафиксированы на лозе из лесных экотопов, самый низкий показатель 118,9 КОЕ/г сухого вещества был зафиксирован на лозе из ампелоценоза на дикорастущих лозах, основную долю в изучаемых грибных сообществах занимали гифальные или плесневые грибы, в среднем их доля составляла 95,1 \%, при этом дрожжи занимали 4,2 \%, а дрожжеподобные грибы 0,7 \% комплекса. На культурных лозах гифальные грибы также занимали бо́льшую часть в структуре грибных сообществ, но при этом их доля была в 1,7 раза меньше, чем на дикоросах. Значительно бо́льшую долю занимали дрожжи $(26,5$ \%) и дрожжеподобные грибы (18,4%).
The assessment of the diversity of fungal communities and the study of the bioindicational significance of mycological indicators is relevant for the biomonitoring of ampelocenoses. This article shows the results of studying the quantitative and qualitative composition of communities of saprotrophic micromycetes associated with annual shoots of wild and cultivated grape plants. The study was conducted in 2020 in various districts of the Krasnodar Territory (Western Ciscaucasia). The objects of the study were wild grape plants from the natural conditions of the forest ecotopes of the state reserve "Utrish "(Anapa district) and Krymsky district, as well as cultivated grape plants of 4 varieties of grapes of different genotypes, cultivated in the plantings of JSC agrofirm «Yuzhnaya» (Temryuk district). Studies have shown that the number of saprotrophic micromycetes associated with the annual vine varies depending on the place of sampling and ranges from 232.9...3203.2 thousand. CFU/g of dry matter on wild grapes and in the range of 118.9...344.1 thousand. CFU / g of dry matter on cultivated grapes. The highest densities of fungal populations - 1119.7 and 3203.2 CFU/g of dry matter were recorded on vines from forest ecotopes, the lowest index of 118.9 CFU / $g$ of dry matter was recorded on vines from ampelocenosis, on wild vines the main share in the studied fungal communities was occupied by hyphal or mold fungi, on average their share was $95.1 \%$, while yeast occupied $4.2 \%$, and yeast-like fungi $0.7 \%$ of the complex. On cultivated vines, hyphal fungi also occupied a large part in the structure of fungal communities, but their share was 1.7 times less than on wild plants. Yeast (26.5\%) and yeast-like fungi (18.4\%) accounted for a much larger share. 
Ключевые слова: ВИНОГРАД, ДИКОРАСТУЩАЯ ФОРМА, ГЕНЕТИЧЕСКИЕ РЕСУРСЫ, МИКРОМИЦЕТЫ
Key words: GRAPES,

WILD FORM, GENETIC RESOURCES, MICROMYCETES.

Введение. В последние годы в сельскохозяйственной и лесной фитопатологии и микологии растет исследовательский интерес к изучению роли грибов в процессах функционирования биоты, моделированию эволюционного развития таксономических единиц, выявлению влияния антропогенных и техногенных факторов на распространение и биологию грибов, накапливается информация о биоразнообразии и вариабельности свойств грибов [1-4]. Важная роль этих организмов в экосистемах сформировалась в процессе их коэволюции с растениями как двух неотъемлемых компонентов - автотрофов и гетеротрофов. Грибы способны осваивать разнообразные экологические ниши и по своей экологической пластичности выделяются среди всех живых организмов [5, 6].

Нет необходимости доказывать, что грибы наряду с многолетними растениям винограда являются важнейшими компонентами ампелоценозов. Филлоплан растений винограда колонизируется большим количеством и разнообразными популяциями микромицетов различной функциональной направленности. Изменения, происходящие в настоящее время в биосфере в результате активной антропогенной деятельности и климатических изменений, оказывают всё большее влияние на среду обитания грибных организмов [7-10]. Процессы, сопровождающие антропогенную и абиотическую трансформацию грибных сообществ в многолетних агроценозах (виноградниках), стимулируют адаптациогенез у грибов, способствуя появлению более агрессивных биотипов среди типичных фитопатогенных доминант, a также появлению новых вредоносных микопатогенов [11, 12].

Стратегия современного адаптивного земледелия подчеркивает важную роль биоценотического подхода в разработке экологизированных 
и биологизированных технологий защиты винограда от болезней. Понимание воздействия антропогенного вмешательства на разнообразие грибов в ампелоценозах имеет первостепенное значение для сохранения возобновляемых ресурсов и повышения фитосанитарной устойчивости биосистем. Кроме того, опыт исследования изменения разнообразия грибных сообществ и изменчивости грибов в условиях техногенной нагрузки разного уровня и качества даёт представление о широких возможностях их использования в оценке качества природных сред [13]. Поэтому проблема оценки разнообразия грибных сообществ, изучения биоиндикационной значимости микологических показателей представляется актуальной для биомониторинга ампелоценозов.

Целью исследований было изучить количественный и качественный состав сообществ сапротрофных микромицетов, ассоциированных с однолетними побегами дикорастущих и культурных растений винограда.

Объекты и методы исследований. Исследования проводили в 2020 году в различных районах Краснодарского края (Западное Предкавказье). Объектами исследования были дикорастущие виноградные растения из естественных условий лесных экотопов государственного заповедника «Утриш» (Анапский район) и Крымского района, а также культурные виноградные растения винограда 4-х сортов, различных по генотипу, возделывающиеся в насаждениях АO агрофирмы «Южная» (Темрюкский район). Сорта винограда:

Pervenec Magaracha - сложный межвидовой гибрид - Vitis vinifera convar. pontica Negr. subconvar. georgica-caspica x (V. vinifera x (V. vinifera $+V$. riparia $+V$. rupestris $)$ );

Bianka - сложный межвидовой гибрид $($ V. vinifera $+V$. labrusca + $V$. riparia $+V$. rupestris $+V$. berlandieri $+V$. aestivalis $+V$. cinerea) $x$ V. vinifera; 
Kober 5 ВВ - подвойный сорт V. berlandieri + V. riparia;

Merlo - V. vinifera convar occidentalis subconvar. Gallica.

Тип климата Темрюкского района (Таманский полуостров) умеренно континентальный, теплый, засушливый. Среднегодовая температура воздуха составляет $+11,1^{\circ} \mathrm{C}$. Продолжительность безморозного периода 193-233 дня. Среднегодовое количество осадков - 400-450 мм. Около трети их годовой нормы приходится на лето, 112 дней в году - осадки менее 0,1 мм. Рельеф Таманского полуострова равнинно-грядово-холмистый, образуемый невысокими (до 150-160 м) грядами с пологими склонами и слабо вогнутыми долинами. Почвы Тамани относятся к южным черноземам. Характерным для них является невысокая гумусированность (2,5-3 \%), значительная мощность (100-130 см) и наличие карбонатов в виде плесени в слое 40-45 см и глубже. Слабая и средняя степень щелочности объясняется присутствием в растворе бикарбоната кальция.

Тип климата территории заповедника «Утриш» можно определить как средиземноморский, с влиянием климата умеренных широт [14]. Средняя годовая температура воздуха составляет $-12,1-12,2{ }^{\circ} \mathrm{C}$, средняя температура января - 2-3 ${ }^{\circ} \mathrm{C}$, июля - 23,3-23,5 ${ }^{\circ} \mathrm{C}$. Средняя годовая величина осадков находится в пределах 570-700 мм. Высота над уровнем моря в районе исследования на участке урочища Широкая щель (межхребтовое понижение) составляет от 40 м до 100 м.

Климат Крымского района умеренно континентальный. Высота над уровнем моря колеблется от 300 до 800 м. Рельеф сильно изрезан, холмистая возвышенность северного и северо-западного склонов Кавказского хребта. Сумма годовых осадков составляет 657 мм (за вегетационный период - 250-355 мм). Среднегодовая температура воздуха $10,6^{\circ} \mathrm{C}$. Основная почвенная разновидность черноземы слитые, мощные, темно-серые лесные и оподзоленные почвы суглинистого механического состава, встречаются дерново-карбонатные [15]. 
В Широкой щели обнаружено и исследовано 5 популяций дикоросов винограда, произрастающих не очень далеко друг от друга (400-600 м между растениями). В лесу Крымского района исследовано 2 популяции. Оценку комплексов сапротрофных микромицетов проводили на 7 образцах дикорастущих лоз и 4 образцах из агроценозов.

Образцы виноградной лозы отбирались в октябре-ноябре и представляли собой однолетние одревесневшие побеги без видимых повреждений/поражений, размером 20-25 см (2-3 глазка от основания побега). Отборы биообразцов дикорастущей лозы производили маршрутнорекогносцировочным методом, культурной лозы - с помощью маршрутных обследований промышленных виноградников.

Численность и структуру комплексов микромицетов, ассоциированных с однолетней виноградной лозой, определяли методом посева разведенной суспензии на плотную питательную среду. Для этого отбирали по 5 образцов однолетних лоз в каждом варианте опыта, промывали водой, затем их измельчали на лабораторной мельнице, полученную смесь тщательно перемешивали и готовили усредненный образец массой 10 г. Перед каждым использованием мельницу тщательно промывали. Подготовленную навеску вносили в стерильную колбу объемом 250 мл с 100 мл стерильной воды. Затем колбу с образцами помещали на лабораторный шейкер DSR-2800P на 15 мин. Для посева использовали суспензию разведения 1:10. Полученную суспензию высевали по 0,3 мл в чашки Петри на картофельно-сахарозный агар (КСА) в 3-х повторностях и равномерно распределяли с помощью шпателя.

Все операции проводили в асептических условиях. Засеянные чашки инкубировали в термостате при $25{ }^{\circ} \mathrm{C}$ в течение 7-10 суток. Лабораторную посуду, принадлежности и питательные среды стерилизовали в автоклаве при Ризб. = 1 атм. в течение часа. Для ингибирования роста бактерий в 
питательную среду добавили антибиотики - стрептомицин сульфат (20 мг/л) и левомицитин (20 мг/л). Помимо этого, отбирали пробы биообразцов массой 10 г по вариантам опыта для определения абсолютно сухой растительной массы. Этот показатель был необходим для расчета пропагул микромицетов на 1 г сухого вещества. Расчет количественного содержания пропагул вели по формуле (1):

$$
\mathrm{K}=(60 \cdot \mathrm{n}) / \mathrm{a} \cdot \mathrm{b} \cdot \mathrm{c},
$$

где $\mathrm{K}$ - КОЕ в 1 г. сухого вещества;

60 - объем суспензии, мл.;

$\mathrm{n}$ - количество колоний, шт.;

a - количество засеянных чашек Петри в одном варианте, шт. $(a=3)$;

$\mathrm{b}$ - объем суспензии, засеянной в одну чашку, мл. $(\mathrm{b}=0,3)$;

c - вес абсолютно сухой растительной массы, г.

Выросшие микромицеты микроскопировались при увеличении х1350. Производился количественный учет колоний мицелиальных грибов, дрожжей и дрожжеподобных грибов. Видовую принадлежность грибов определяли по отечественным и зарубежным определителям [16-20] с использованием микроскопа Micros MC 20. Статистическую обработку данных проводили с использованием Microsoft Exel 2000, вычисляли среднее значение и стандартное отклонение.

В Широкой щели исследовано 5 популяций дикоросов винограда, произрастающих не очень далеко друг от друга (400-600 м между растениями). В лесу Крымского района исследовано 2 популяции. Всего оценку комплексов сапротрофных микромицетов проводили на 7 образцах дикорастущих лоз и 4 образцах из агроценозов. 
Обсуждение результатов. Проведенные исследования показали, что численность сапротрофных микромицетов, ассоциированных с однолетней лозой различна в зависимости от места отбора образца и колеблется в пределах 232,9...3203,2 тыс. КОЕ/г сухого вещества на дикорастущем винограде и в пределах 118,9...344,1 тыс. КОЕ/г сухого вещества на культурном винограде (рис. 1).

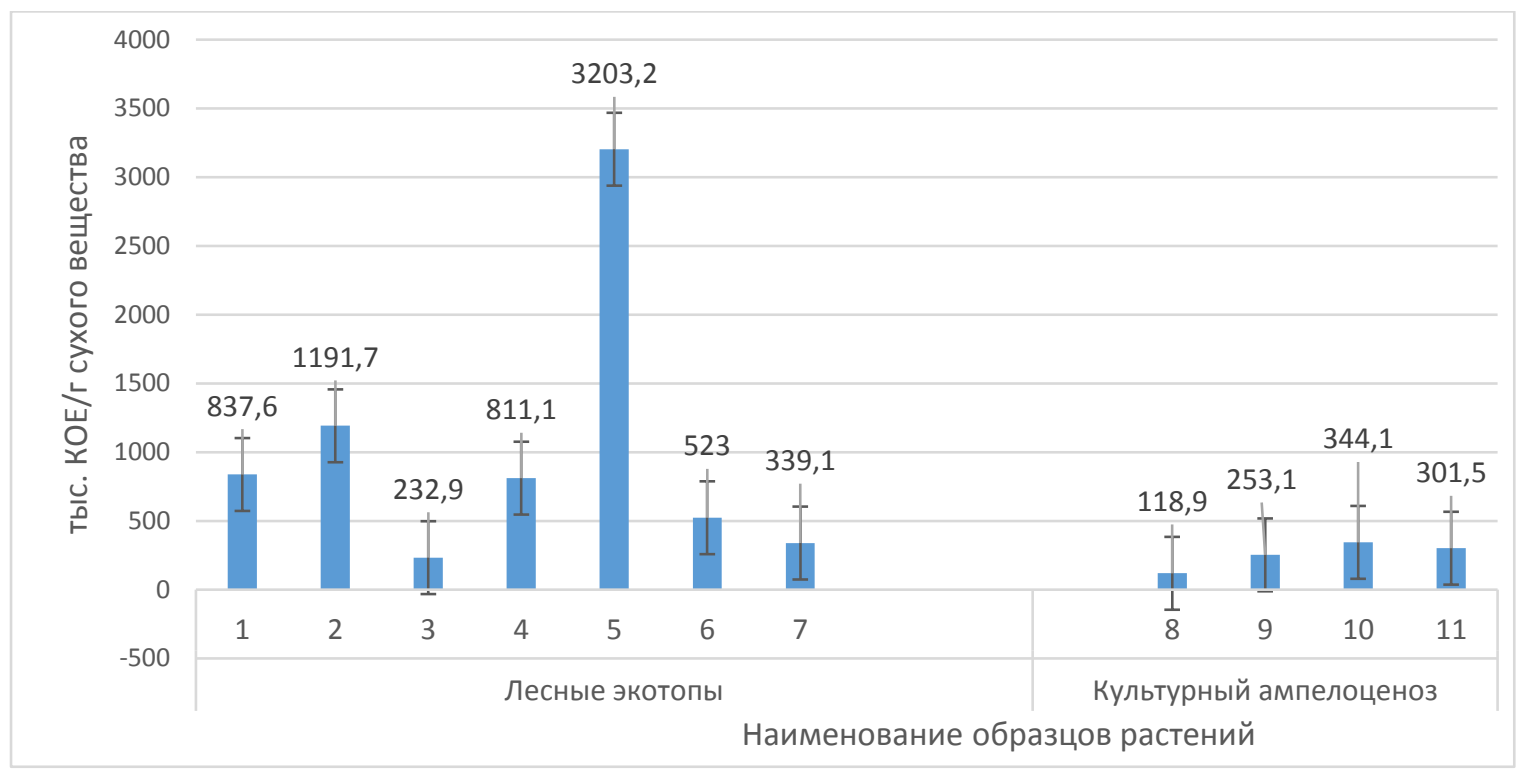

Рис. 1. Общее количество сапротрофных микромицетов в комплексах, связанных с виноградом (однолетняя лоза), Западное Предкавказье, 2020 г.

Самые высокие показатели плотности грибных популяций - 1119,7 и 3203,2 КОЕ/г сухого вещества - были зафиксированы на лозе из лесных экотопов, самый низкий показатель 118,9 КОЕ/г сухого вещества был зафиксирован на лозе из ампелоценоза, определяющим фактором здесь явилась влажность образцов.

Структура сапротрофных микромицетов ассоциированных с однолетней лозой значительно отличалась между дикорастущим и культурным виноградом. На дикорастущих лозах основную долю в изучаемых грибных сообществах занимали гифальные или плесневые грибы, в среднем их доля составляла 95,1%, при этом дрожжи занимали 4,2 \%, а дрожжеподобные грибы 0,7 \% комплекса (табл. 1). 
Плодоводство и виноградарство Юга России № 70(4), 2021 г.

Таблица 1 - Структура комплексов сапротрофных микромицетов, ассоциированных с однолетней виноградной лозой по морфологическим признакам, лесные экосистемы Западного Предкавказья, октябрь-ноябрь 2020 г.

\begin{tabular}{|c|c|c|c|c|}
\hline \multirow{2}{*}{$\begin{array}{c}\text { Номер } \\
\text { образца }\end{array}$} & Название образца & \multicolumn{3}{|c|}{ в \% от общей численности микромицетов } \\
\cline { 3 - 5 } & & $\begin{array}{c}\text { Гифальные } \\
\text { (плесневые) } \\
\text { грибы }\end{array}$ & Дрожжи & Дрожжеподобные \\
\hline 1 & Kр.1 & 95,9 & 3,7 & 0,4 \\
\hline 2 & Кр.2 & 93,7 & 5,9 & 0,4 \\
\hline 3 & Шир.1 & 90,8 & 8,1 & 1,1 \\
\hline 4 & Шир.2 & 94,2 & 4,2 & 1,6 \\
\hline 5 & Шир.3 & 99,8 & 0,2 & 0,0 \\
\hline 6 & Шир.4 & 96,9 & 3,1 & 0,0 \\
\hline 7 & Шир.5 & 94,2 & 4,2 & 1,6 \\
\hline & Среднее & $\mathbf{9 5 , 1}$ & $\mathbf{4 , 2}$ & $\mathbf{0 , 7}$ \\
\hline
\end{tabular}

На культурных лозах гифальные грибы также занимали бо́льшую часть в структуре грибных сообществ, но при этом их доля была в 1,7 раза меньше, чем на дикоросах. Значительно бо́льшую долю занимали дрожжи (26,5 \%) и дрожжеподобные грибы (18,4%) (табл. 2).

Таблица 2 - Структура комплексов сапротрофных микромицетов, ассоциированных с однолетней виноградной лозой по морфологическим признакам, ампелоценозы, Западное Предкавказье, октябрь-ноябрь 2020 г.

\begin{tabular}{|c|l|c|c|c|}
\hline \multirow{2}{*}{$\begin{array}{c}\text { Номер } \\
\text { образца }\end{array}$} & \multicolumn{1}{|c|}{\begin{tabular}{c}
\multicolumn{2}{|c|}{ Вазвание образца } \\
\cline { 3 - 5 }
\end{tabular}} & $\begin{array}{l}\text { Гифальные общей численности микромицетов } \\
\text { (плесневые) } \\
\text { грибы }\end{array}$ & Дрожжи & Дрожжеподобные \\
\hline 8 & $\begin{array}{l}\text { Промышленный виноградник (сорт винограда } \\
\text { Первенец Магарача) }\end{array}$ & 36,3 & 42,0 & 21,7 \\
\hline 9 & $\begin{array}{l}\text { Промышленный виноградник (сорт винограда } \\
\text { Бианка) }\end{array}$ & 31,5 & 29,5 & 39,0 \\
\hline 10 & $\begin{array}{l}\text { Промышленный виноградник (сорт винограда } \\
\text { Кобер 5ББ) }\end{array}$ & 99,5 & 0,0 & 0,5 \\
\hline 11 & $\begin{array}{l}\text { Промышленный виноградник (сорт винограда } \\
\text { Мерло) }\end{array}$ & 53,0 & 34,7 & 12,3 \\
\hline Среднее & $\mathbf{5 5 , 1}$ & $\mathbf{2 6 , 5}$ & $\mathbf{1 8 , 4}$ \\
\hline
\end{tabular}


Плодоводство и виноградарство Юга России № 70(4), 2021 г.

Анализ грибных сообществ на однолетней лозе винограда, произраставшего в ценозах с различной антропогенной нагрузкой, выявил следующее соотношение таксонов (табл. 3, 4).

Таблица 3 - Таксономическая структура гифальных грибов, ассоциированных с однолетней лозой дикого винограда, в \% от их численности, 2020 г.

\begin{tabular}{|c|c|c|c|c|c|c|c|c|c|c|}
\hline $\begin{array}{l}\text { Номер } \\
\text { образца }\end{array}$ & Название образца & 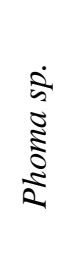 & 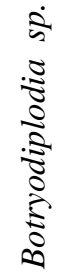 & 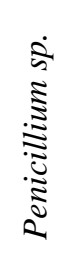 & 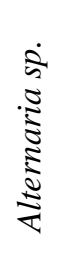 & 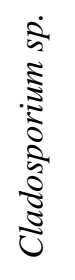 & 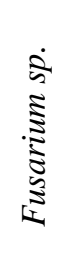 & 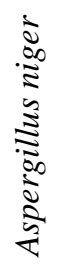 & 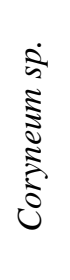 & 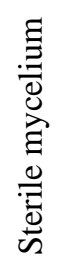 \\
\hline 1 & Kp.1 & 59,4 & 33,7 & 0,0 & 1,0 & 1,3 & 0,0 & 0,0 & 4,0 & 0,0 \\
\hline 2 & Kр.2 & 34,1 & 52,6 & 0,0 & 0,3 & 7,9 & 0,2 & 0,3 & 3,7 & 0,1 \\
\hline 3 & Шир.1 & 86,0 & 7,0 & 0,0 & 1,3 & 10,0 & 0,3 & 0,0 & 0,7 & 6,0 \\
\hline 4 & Шир.2 & 23,8 & 58,1 & 0,2 & 3,9 & 13,8 & 0,0 & 0,0 & 0,0 & $\overline{0,0}$ \\
\hline 5 & Шир.3 & 70,6 & 22,1 & 0,0 & 0,4 & 3,4 & 0,0 & 0,0 & 1,7 & $\overline{0,0}$ \\
\hline 6 & Шир.4 & 79,4 & 15,4 & 0,0 & 1,3 & 3,6 & 0,0 & 0,0 & 0,0 & 0,0 \\
\hline 7 & Шир.5 & 62,6 & 21,4 & 0,0 & 1,6 & 8,4 & 0,0 & 0,0 & 2,3 & 0,4 \\
\hline \multicolumn{2}{|l|}{ Среднее } & 59,3 & 30,0 & 0,03 & 1,3 & 6,8 & 0,07 & 0,04 & 1,8 & 0,8 \\
\hline
\end{tabular}

Таблица 4 -Таксономическая структура гифальных грибов, связанных с однолетней лозой культивируемого винограда, в \% от их численности, 2020 г.

\begin{tabular}{|c|c|c|c|c|c|c|c|}
\hline $\begin{array}{c}\text { Номер } \\
\text { образца }\end{array}$ & Название образца & 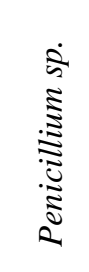 & 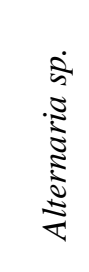 & 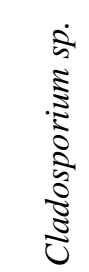 & 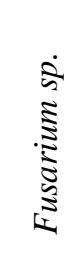 & 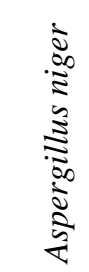 & 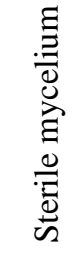 \\
\hline 8 & $\begin{array}{l}\text { Промышленный виноградник } \\
\text { (сорт винограда Первенец Магарача) }\end{array}$ & 7,8 & 11,4 & 55,6 & 3,1 & 16,7 & 5,4 \\
\hline 9 & $\begin{array}{l}\text { Промышленный виноградник } \\
\text { (сорт винограда Бианка) }\end{array}$ & 0,0 & 0,9 & 96,8 & 0,8 & 1,5 & 0,0 \\
\hline 10 & $\begin{array}{l}\text { Промышленный виноградник } \\
\text { (сорт винограда Кобер 5ББ) }\end{array}$ & 0,0 & 0,8 & 97,1 & 1,3 & 0,8 & 0,0 \\
\hline 11 & $\begin{array}{l}\text { Промышленный виноградник } \\
\text { (сорт винограда Мерло) }\end{array}$ & 6,3 & 1,8 & 86,6 & 3,2 & 2,1 & 0,0 \\
\hline & Среднее & 3,5 & 3,7 & 84,0 & 2,1 & 5,3 & 1,4 \\
\hline
\end{tabular}


Анализ перечня всех таксонов гифальных грибов, которые были обнаружены при изучении таксономического состава грибных комплексов виноградной лозы из различных экотопов, позволил определить частоту встречаемости и частоту доминирования разных родов микромицетов в изученной эконише - на однолетней лозе. Из 8 выявленных нами таксонов грибов первое место по частоте встречаемости на дикорастущем винограде заняли грибы Phoma sp., Botryodiplodia sp., Cladosporium sp., Alternaria sp. (100 \%), второе место - Coryneum sp. (70 \%). Следующую группу микромицетов с частотой встречаемости 14 \% составили: Penicillium sp., Fusarium sp. и Aspergillus niger Tiegh. Из 5 выявленных таксонов гифальных грибов, ассоциированных с однолетней лозой из промышленных насаждений винограда, наиболее часто встречаемыми видами отмечены Cladosporium sp. Aspergillus niger, Alternaria sp., Fusarium sp. (100 \%), на втором месте Penicillium sp. (50\%).

В качестве доминанты в лесных экосистемах на однолетней лозе винограда обнаружены микромицеты рода Phoma Sacc. В качестве субдоминанты на дикорастущей лозе были отмечены грибы рода Botryodiplodia Sacc. Следует также отметить выявленные грибы других родов Cladosporium Link, Alternaria Nees и Coryneum Nees. В качестве минорных компонентов были выделены грибы из родов Penicillium Link, Fusarium Link и вид Aspergillus niger Tiegh. При изучении комплексов сапротрофных микромицетов, ассоциированных с однолетней лозой, в ампелоценозах в качестве доминанты выделились грибы рода Cladosporium Link. Необходимо отметить также вид Aspergillus niger и грибы из родов Fusarium Link Alternaria Nees и Penicillium Link. В обеих группах биообразцов винограда как часто встречаемые виды были выявлены характерные для филлосферы различных растений альтернариевые грибы. 
Плодоводство и виноградарство Юга России № 70(4), 2021 г.

Bbыводы. Таким образом, анализ таксономической структуры грибных сообществ в экосистемах с различной антропогенной нагрузкой позволил выявить как общие закономерности, так и некоторые различия. Для обеих исследованных групп биообразцов однолетней лозы винограда выявлена монодоминантная структура комплексов микромицетов, но в составе доминантов отмечаются различия. Следует также отметить, что различия в количестве и соотношении таксонов грибов исследованных биообразцов связаны, вероятно, с различной антропогенной нагрузкой (обработки пестицидами, искусственные формировки и т.д.). Полученные результаты показывают целесообразность дальнейших исследований по изучению разнообразия грибных сообществ и выявлению биоиндикационной значимости микологических показателей в ампелоценозах.

\section{Литература}

1. Desprez-Loustau, ML., Aguayo, J., Dutech, C. et al. An evolutionary ecology perspective to address forest pathology challenges of today and tomorrow. Annals of Forest Science 73, 45-67 (2016). https://doi.org/10.1007/s13595-015-0487-4

2. Hazael Hernandez, Luis R. Martinez Relationship of environmental disturbances and the infectious potential of fungi / Microbiology 2018 Mar; 164(3): 233-241. Published online 2018 Feb 5. https://doi.org/10.1099/mic.0.000620

3. Terekhova V.A., Semenova T.A. The structure of micromycete communities and their synecologic interactions with basidiomycetes during plant debris decomposition. Microbiology 74, 91-96 (2005). https://doi.org/10.1007/s11021-005-0034-7

4. Selçuk F., Hüseyin E., Şahin A., Cebeci C. Hyphomycetous fungi in several forest ecosystems of Black sea provinces of Turkey / Mycosphere 5 (2): 334-344 (2014) Doi 10.5943/mycosphere/5/2/7 https://www.mycosphere.org/pdf/Mycosphere_5_2_7.pdf

5. Slepecky RA, Starmer WT. Phenotypic plasticity in fungi: a review with observations on Aureobasidium pullulans. Mycologia. 2009 Nov-Dec;101(6):823-32. https://doi.org/10.3852/08-197

6. Wrzosek, M., Ruszkiewicz-Michalska, M., Sikora, K. et al. The plasticity of fungal interactions. Mycol Progress 16, 101-108 (2017). https://doi.org/10.1007/s11557016-1257-X

7. Yaohui Bai1, Qiaojuan Wang, Kailingli Liao, Zhiyu Jian, Chen Zhao, Jiuhui Qu1 Fungal Community as a Bioindicator to Reflect Anthropogenic Activities in a River Ecosystem / Front. Microbiol., 21 December 2018 | https://doi.org/10.3389/fmicb.2018.03152

8. Abrego, N., Crosier, B., Somervuo, P. et al. Fungal communities decline with urbanization - more in air than in soil / The ISME Journal volume 14, pages 2806-2815(2020) -https://doi.org/10.1038/s41396-020-0732-1 
9. Jackson R. S., Wine Science (Fifth Edition) Principles and Applications Food Science and Technology, 331-374 (2020) https://doi.org/10.1016/B978-0-12-816118$0.00005-2$

10. André C.Velásquez, Christian Danve M.Castroverde, Sheng Yang He. Current Biology, 28(10) 619-634 (2018) https://doi.org/10.1016/j.cub.2018.03.054

11. Yurchenko E.G., Savchuk N.V., Porotikova E.V., Vinogradova S.V. First Report of Grapevine (Vitis sp.) Cluster Blight Caused by Fusarium proliferatum in Russia / Plant Disease 104(3) 991 (2019) - https://doi.org/10.1094/PDIS-05-19-0938-PDN

12. Юрченко Е.Г., Буровинская М.В. Полевая устойчивость сортов винограда к альтернариозу / Плодоводство и ягодоводство России. 2019 . № 58. C. 194-200. https://doi.org/10.31676/2073-4948-2019-58-194-200

13. Terekhova V.A. Micromycetes in ecological evaluation of aquatic and terrestrial ecosystems / V.A. Terekhova; A.N. Severtsov Institute of Ecology and Evolution of RAS, Institute of Ecological Soil Science of Moscow Lomonosov Statr University. - M.: Nauka, 2007 - 215 p. - ISBN 5-02-034200-9

14. Ткаченко Ю.Ю., Денисов В.И. Климат // Атлас. Государственный природный заповедник «Утриш». Научные труды. Анапа, 2013. Т. 2. С. 32-38.

15. Адаптивный потенциал винограда в условиях стрессовых температур зимнего периода: методические рекомендации / Е.А. Егоров [и др.]. Краснодар: СКЗНИИСиВ, 2006. 156 с.

16. Simmons E.G. Alternaria. An identification manual, CBS Biodiversity series, 775 p. (2007)

17. Nelson P.E., Toussoun T.A. et al. Fusarium Species: An Illustrated Manual for Identification. - University Park and London: Pennsylvania State University Press, 1983. $193 \mathrm{p}$.

18. База данных Species Fungorum. - URL: http://www.speciesfungorum.org/ Names/NamesRecord.asp?RecordID=270431 (дата обращения 03.05.2021).

19. Leslie, J.F. The Fusarium Laboratory Manual / J.F. Leslie, B.A. Summerell. Oxford: Blackwell Publishing Ltd., 2006. - 388 p.

20. Саттон Д., Фотергилл А., Ринальди М. Определитель патогенных и условно патогенных грибов. М.: Мир, 2001. 486 с.

\section{References}

1. Desprez-Loustau, ML., Aguayo, J., Dutech, C. et al. An evolutionary ecology perspective to address forest pathology challenges of today and tomorrow. Annals of Forest Science 73, 45-67 (2016). https://doi.org/10.1007/s13595-015-0487-4

2. Hazael Hernandez, Luis R. Martinez Relationship of environmental disturbances and the infectious potential of fungi / Microbiology 2018 Mar; 164(3): 233-241. Published online 2018 Feb 5. https://doi.org/10.1099/mic.0.000620

3. Terekhova V.A., Semenova T.A. The structure of micromycete communities and their synecologic interactions with basidiomycetes during plant debris decomposition. Microbiology 74, 91-96 (2005). https://doi.org/10.1007/s11021-005-0034-7

4. Selçuk F., Hüseyin E., Şahin A., Cebeci C. Hyphomycetous fungi in several forest ecosystems of Black sea provinces of Turkey / Mycosphere 5 (2): 334-344 (2014) Doi 10.5943/mycosphere/5/2/7 https://www.mycosphere.org/pdf/Mycosphere_5_2_7.pdf

5. Slepecky RA, Starmer WT. Phenotypic plasticity in fungi: a review with observations on Aureobasidium pullulans. Mycologia. 2009 Nov-Dec;101(6):823-32. https://doi.org/10.3852/08-197 
6. Wrzosek, M., Ruszkiewicz-Michalska, M., Sikora, K. et al. The plasticity of fungal interactions. Mycol Progress 16, 101-108 (2017). https://doi.org/10.1007/s11557016-1257-X

7. Yaohui Bai1, Qiaojuan Wang, Kailingli Liao, Zhiyu Jian, Chen Zhao, Jiuhui Qu1 Fungal Community as a Bioindicator to Reflect Anthropogenic Activities in a River Ecosystem / Front. Microbiol., 21 December 2018 | https://doi.org/10.3389/fmicb.2018.03152

8. Abrego, N., Crosier, B., Somervuo, P. et al. Fungal communities decline with urbanization-more in air than in soil / The ISME Journal volume 14, pages 28062815(2020) -https://doi.org/10.1038/s41396-020-0732-1

9. Jackson R. S., Wine Science (Fifth Edition) Principles and Applications Food Science and Technology, 331-374 (2020) https://doi.org/10.1016/B978-0-12-816118$0.00005-2$

10. André C.Velásquez, Christian Danve M.Castroverde, Sheng Yang He. Current Biology, 28(10) 619-634 (2018) https://doi.org/10.1016/j.cub.2018.03.054

11. Yurchenko E.G., Savchuk N.V., Porotikova E.V., Vinogradova S.V. First Report of Grapevine (Vitis sp.) Cluster Blight Caused by Fusarium proliferatum in Russia / Plant Disease 104(3) 991 (2019) - https://doi.org/10.1094/PDIS-05-19-0938-PDN

12. Yurchenko E.G., Burovinskaya M.V. Polevaya ustojchivost' sortov vinograda k al'ternariozu / Plodovodstvo i yagodovodstvo Rossii. 2019. № 58.

S. 194-200. https://doi.org/10.31676/2073-4948-2019-58-194-200

13. Terekhova V.A. Micromycetes in ecological evaluation of aquatic and terrestrial ecosystems / V.A. Terekhova; A.N. Severtsov Institute of Ecology and Evolution of RAS, Institute of Ecological Soil Science of Moscow Lomonosov Statr University. - M.: Nauka, 2007 - 215 r. - ISBN 5-02-034200-9

14. Tkachenko Yu.Yu., Denisov V.I. Klimat // Atlas. Gosudarstvennyj prirodnyj zapovednik «Utrish». Nauchnye trudy. Anapa, 2013. T. 2. S. 32-38.

15. Adaptivnyj potencial vinograda $\mathrm{v}$ usloviyah stressovyh temperatur zimnego perioda: metodicheskie rekomendacii / E.A. Egorov [i dr.]. Krasnodar: SKZNIISiV, 2006. $156 \mathrm{~s}$.

16. Simmons E.G. Alternaria. An identification manual, CBS Biodiversity series, 775 p. (2007)

17. Nelson P.E., Toussoun T.A. et al. Fusarium Species: An Illustrated Manual for Identification. - University Park and London: Pennsylvania State University Press, 1983. - $193 \mathrm{p}$.

18. Baza dannyh Species Fungorum. - URL: http://www. speciesfungorum.org/ Names/NamesRecord.asp?RecordID=270431 (data obrashcheniya 03.05.2021).

19. Leslie, J.F. The Fusarium Laboratory Manual / J.F. Leslie, B.A. Summerell. Oxford: Blackwell Publishing Ltd., 2006. - 388 p.

20. Satton D., Fotergill A., Rinal'di M. Opredelitel' patogennyh i uslovno patogennyh gribov. M.: Mir, 2001. 486 s. 